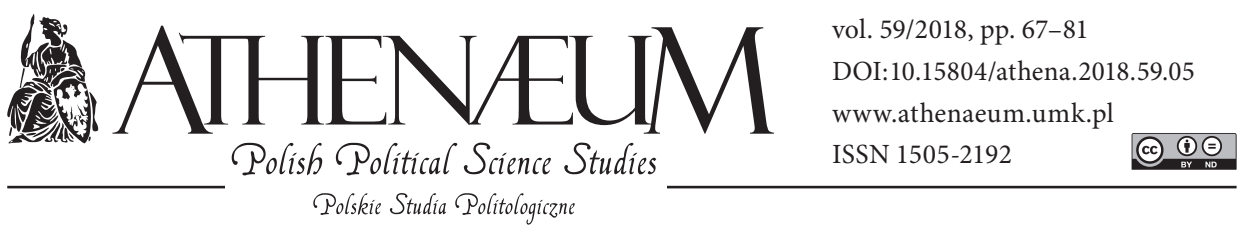

\title{
METHODOLOGICAL CRITIQUE IN SOCIAL SCIENCES - CHOSEN ASPECTS
}

\author{
KRYTYKA METODOLOGICZNA W NAUKACH SPO ŁECZNYCH - \\ WYBRANE ASPEKTY
}

Stanisław Juszczyk*

\begin{abstract}
The work discusses a methodological critique of research concepts, designed and introduced in social sciences, under the positivist and humane paradigms and in 'mixed' research. Attention is paid to consecutive stages of a research project (its key points are indicated) and also to needed reflection as well as seeking answers to numerous questions concerning the right structure of projects described in academic articles and monographs.
\end{abstract}

Keywords: methodology of social sciences, methodological criticism, quantitative, qualitative research, and mixed research
Praca poddaje pod dyskusję krytykę metodologiczną koncepcji badawczych projektowanych i realizowanych w naukach społecznych, w ramach paradygmatów pozytywistycznego, humanistycznego oraz w badaniach „mieszanych”. Zwrócono uwagę na kolejne etapy projektu badawczego (z jego kluczowymi punktami), a także na niezbędną refleksję i poszukiwanie odpowiedzi na liczne pytania dotyczące właściwej konstrukcji projektów opisywanych w artykułach czy też w monografiach naukowych.

Słowa kluczowe: metodologia nauk społecznych, krytyka metodologiczna, badania ilościowe, jakościowe i mieszane

* University of Silesia in Katowice, Faculty of Education and Psychology.

ORCID: https://orcid.org/0000-0002-7775-6303. 


\section{METHODOLOGICAL SCIENTIFIC CRITICISM}

The methodology of sciences is developing systematically, by constructing new and modernising the existing theories and models, improving the existing research methods and techniques, by developing new research tools and standardising them, through the operationalisation of qualitative variables (referred to as unmeasurable, descriptive), consisting in replacing them with quantitative, i.e., measurable variables but, above all, by giving, confronting and comparing the results of research into similar occurrences and processes, carried out on similar survey samples employing similar research methods and techniques, but at a different time and in a different field of research. This leads to scientific criticism, enabling to assess the reliability of research carried out, its repeatability, to indicate its cognitive and utilitarian values, and also to indicate further exploration areas. Due to a multitude of paradigms functioning in social sciences, quantitative, qualitative and 'mixed' research strategies, diversified populations and methods for selecting a survey sample, used research methods and techniques, statistical tests or qualitative analyses, a person carrying out a critical analysis is required to have high methodological competences and statistical skills.

The term 'criticism' can be defined as a 'critical opinion or comment, especially in the case of artistic or literature works; a critical discussion/analysis of a certain particular problem, issue; the art of criticism' (c.f. American Heritage Dictionaries, 2005, p. 1). In the Polish language dictionary edited by Witold Doroszewski (2017), we find that the word 'criticism' means the art of judging, adjudicating; in the methodology, it is a science-based analysis and assessment of a certain area of human activity and its works due to specific values: cognitive, ethical, aesthetic, and practical ones. The term that is more useful for us is 'scientific criticism', being a science-based analysis and assessment of scientific works in terms of their cognitive value and practicability as well as formal correctness (logical scientific criticism); in terms of substantive compliance with the established facts (empirical scientific criticism); legal validity and the correctness of used methods (methodological scientific criticism); the assumed purpose and scientific concepts (theoretical scientific criticism) and in terms of philosophical assumptions (philosophical scientific criticism). It turns out that 'scientific criticism' or 'research criticism' are terms that are often used in the world's methodological literature, and furthermore also other terms can be found in it such as: critical analyses, review/commentary/checking, evaluation 
and assessment (c.f. CyberNurse, 2005). Therefore, methodological scientific criticism is related to: critical analysis of theories describing a given occurrence or process; a critical assessment of the results of research published by various authors in the form of monographs, articles and conference papers; critical analysis of the source literature containing both theoretical bases for research, and its sample results; criticism of methodological concepts of designed basic and applied research (critical analysis of the research structure); a critical assessment of Master's, doctoral, and postdoctoral dissertations (academic promotion works in general); critical analysis of individual and team, national and international scientific research projects submitted for assessment; critical analysis of proposed research methods, techniques and tools; critical analysis of the results of empirical research; a critical assessment of the use of statistical techniques and tools; a critical assessment of the conclusions from research and proposals for putting into practice. The term of methodological scientific criticism is therefore very broad-ranging, wide, covers analysis of many other terms, research methods and activities undertaken by researchers when designing, realising, and preparing research results.

An ability to critically evaluate individual elements of a research procedure (especially in research carried out in the positivist paradigm) is a necessary skill of researchers from different scientific disciplines, in order to assess the integrity and usability of research results and conclusions formulated. Criticism of research is a mechanism that enables to repeat research in order to confirm the reliability of the results achieved, and even to collect further information (Polit \& Beck, 2006). In general, the ability to criticise a research procedure is automatic for many experienced researchers having considerable knowledge and skills in the methodology of research which skills cover the following: identifying the object of research, formulating the objectives of research, research questions and hypotheses, selecting a survey sample, constructing a research project, verifying the established research procedures and developed tools, acquiring data and analysing data, using statistical methods and tests, and interpreting the results achieved. Without an objective interpretation of the acquired data, breakthroughs in science and the development of science would be impossible. The driving force of fact-based research, in a traditional sense, is an ability to measure and assess an occurrence (its quantification), and also relations between occurrences, regardless of nature of these occurrences (Vance, Talley, Azuero, Pearce, \& Christian, 2013, p. 67). Such ability makes it possible to formulate particular research questions and verifiable hypothesis so that statistical proce- 
dures can be applied to the data acquired for the purposes of reducing them to discrete sets and including their specific areas; this process is often referred to as a reduction and is one of the objectives of science (Voelker \& Orton, 1993). From such sets, one may derive objective interpretations which, after some time, together with other authors interpretations, studying the same occurrence, may cause drawing conclusions for putting into practice, and may furthermore cause framing further research questions, and finding answers to them through further research may bring benefits both for science, and for practice.

The result of critical evaluation of research results described in academic literature, required from researchers, is the continuation of many improved practical activities related to putting research results into practice and modernising research methods and techniques. Hence, a critical assessment of research results being described in the literature of a given scientific discipline or sub-discipline is so significant. Proceeding this way should be natural for all researchers, who should keep trace of the publication of the latest research in an area in which a given researcher or a given group of researchers is interested, verify the devised structures of a research process, and also their results and discussion in order to get to know the latest model of an explored occurrence. Proceeding this way should be accepted by junior research workers for whom studying literature systematically and frequently plays a significant role in developing habits in them that are necessary for achieving scientific professionalism. For this reason it is demanded that the theoretical basis of designed quantitative scientific research includes critical analysis of theories describing an occurrence being studied and of the latest results of research of other authors. Unfortunately, we may rarely meet such critical analysis of the results of someone else's research in academic publications, articles more often only discuss selected results of such research and descriptions of those aspects of a theory which the authors are going to use when interpreting their own results. Research procedures are analysed selectively, in order to gain information, e.g., about the method of selecting a survey sample, or the specificity of the field of research. It is rare to find another article by the same author or by the same team that carried out their research again and achieved the same (or similar) results (performed auto-replication), confirming thereby the reliability of their research. Reliable scientific research has a capacity of being carried out again, i.e., a capacity of being replicated in order to make sure whether or not the regularities, dependencies, relations and courses observed are a repeatable course of an occurrence, process or event. So achieving similar (within the limits of a permissible error) research results by the same 
or other team of researchers, also individual researchers under different field conditions, on a different sample is confirmation of its reliability. Replications are also confirmation of the rightness of theories or models used, or modify them. Kazimierz Ajdukiewicz (1983, p. 71), a philosopher and methodologist, wrote that: "[...] scientific cognition is a cognition that is intersubjectively communicable and intersubjectively controlled. It is intersubjectivity that is - as is seems - a characteristic feature of rational cognition".

Also sociologists Chava Frankfort-Nachmias and David Nachmias (2001, pp. 29-30) write about the subject of the requirement of repeatability of research results, explaining the significance of intersubjectivity in scientific studies in greater detail: "[...] To be intersubjective means that knowledge (generally) and research methodology (particularly) need to be communicable. Therefore, if one researcher carries out research, then other researcher may carry it out again and compare the two sets of results with each other. If the right methodology and (which we assume) conditions under which the research was carried out were used, or the events that occurred were not changed, then we have the right to expect similar results".

So every researcher should carry out their research again many times changing the size of a sample, place and time of research before publishing their results. The method of selecting a survey sample and its size are the factors that significantly affect the results achieved. In an intentional replication of scientific research, we leave certain factors unchanged, whereas we manipulate others, each time changing a group of factors being manipulated. Unfortunately, carrying out research again does not result in another possibility of publishing its results because editorial teams in scientific magazines expect to publish new, original research results that should bring a specific contribution to the concerned scientific discipline or subdiscipline rather than repeat interpretations or criticism of previous research (cf. www.educationalrev.us.edu.pl). Here, it needs to be stressed that due to the limit of pages, words, and even the limit of characters including spaces in an article, its author needs to carefully devise its structure and the substantive content so that the article is not rejected for formal reasons. However, an ability to critically evaluate the results of someone else's research allows a researcher to avoid traps, errors or simplifications and is a good way of improving their own research technique and of honing their own research and methodological skills, leading to achieving professionalism (Juszczyk, 2011, pp. 17-32).

When publishing research results, we need to pay attention to the title of an article or monograph. It should illustrate both the researcher's concept, and the 
object of research, the data collection methods used, and include dependencies between variables and be comprehensible and not too lengthy at the same time. As the titles of scientific works not always fully illustrate the core of research, keywords are introduced in order to make it easier for the readers to determine dependencies being analysed, determine the usefulness of research and to place it in a specific area of scientific cognition.

Interpretations of features (advantages and disadvantages) of scientific research in sociology, political science, pedagogy and psychology, designed in the positivist or humane paradigm, containing the results of this research or characteristics of its structure can be found in many survey works, and for example in widely spread monographs: Earl R. Babbie (2013), Alan Bryman (2004), Chava Frankfort-Nachmias \& David Nachmias (2001), Norman K. Denzin \& Yvonna S. Lincoln (2000), and Abbas Tashakkori \& Charles Teddlie (2003).

The article discusses a hermeneutical analysis of academic texts related to the methodological criticism of individual elements of the structure of designed quantitative, qualitative, and 'mixed' research, published in the form of articles, chapters in collective works and monographs. Dilemmas of researchers constructing research projects, asking themselves critical questions at each stage of a research procedure, will be described, critical situations for the correctness of a research process, and also general methodological requirements of scientific publications will be indicated. Besides the description of a critical approach of chosen researchers, the work also includes the author's reflection, carrying out empirical research.

\section{METHODOLOGICAL CRITICISM OF QUANTITATIVE RESEARCH PROCEDURE}

A quantitative, positivist approach is adopted when a researcher starts designing research with critical analysis of a theory (or hypothesis) describing an occurrence and falsifies the hypothesis by getting confirmation of its rightness or rejection at an adopted level of confidence. Quantitative research, realised in the positivist paradigm, belongs to the category of empirical studies or statistical studies. Such research projects include more traditional methods using which research in psychology and behavioural sciences is carried out. Quantitative research main projects are experimental and quasi-experimental studies, structures that are used as pre-tests or post-tests, and in research itself monitoring 
variables, randomisation take place and significant and reliable measurements are carried out, whereas generalising the conclusions from a sample for the general population is its objective. Data in quantitative studies are encoded according to a priori operationalised and standardised definitions. Quantitative research projects and publications containing quantitative research results are easier for carrying out scientific methodological criticism on them compared to criticism of qualitative research, due to its matter-of-factness and a higher level of objectivity (cf. Vance et al., 2013, pp. 67-75).

Preparing to undertake research, and then to publish it, a researcher needs to pose themselves a number of critical questions to which they should find constructive answers. One can meet the elements of methodological scientific criticism discussed below in research projects prepared by individual researchers or scientific teams, and also in academic articles and monographs. The first element of scientific criticism is the question about a cognitive objective of research: Is this research necessary? What can it contribute to the scientific discipline and practice? Will it broaden the knowledge about an occurrence? If the answers will be negative, this means there is no need to carry out this research. The next questions should concern a research project itself, based on the source literature, e.g.: Is there a theory describing the occurrence being studied? If there is none, will a researcher manage to acquire data, and then to interpret them? Who will be subject to the research? What will be the structure of a planned research? (cf. Carter, 2006; Valente, 2003, pp. 130-142).

The next element of research criticism is related to critical analysis of the literature, concerning the object of research. Questions a researcher should ask themselves could be the following: Is a review/analysis of the literature sufficient to design reliable research? Is the literature being analysed up-to-date (published in the last five years)? Are primary or secondary sources used? Is a review of the literature edited well, does it have introduction and summary, was the latest model of an explored occurrence drafted? The researcher should also answer the following question: what has been written about the issue being studied so far?

A further stage of a critical look at research includes formulating research questions and hypotheses. This stage of scientific criticism is the most important because it is directly related to the objective of research. The most frequent, complementary questions are framed, such as: who, what, when, where, why, and how? The researcher should think whether or not the questions are framed clearly. Do they contain the objective of research in them? (cf. Boswell \& Cannon, 2011, p. 294). 
Hypotheses should contain assumed relations between variables. Here, it should be mentioned that quantitative research should be designed so as to foresee using statistical methods for preparing the results of research and for falsifying hypotheses. A hypothesis may be defined "as an assumption, a simple statement about predicted relations between variables" (Polit \& Beck, 2006, p. 501). Simply speaking, a hypothesis may predict, suggest, assume, explain or verify the quality, a property or a feature of people, things or of an environment. We often use the saying about 'hypothetical situations' in colloquial language. That is, a hypothesis proposes a solution to a research problem, is a hypothetical answer to a research question, and the researcher formulates a hypothesis at a certain level of likelihood. Before formulating hypotheses, the researcher should ask themselves the following questions: Did they describe all of the most important variables? Did they perform their operationalisation, i.e., indexation? (after all, we place variable indicators in research tools often constructed by a researcher) Are the hypotheses formulated clearly? Do the hypotheses illustrate the objective of research? (cf. Boswell \& Cannon, 2011, p. 295)

Finally, we are reaching selection of research methods and techniques (data collection) that determines the way of framing research questions and their substantive content. The primary research problem determines the choice of the principal research method or technique, and detailed research questions may indicate the need to employ further research methods or techniques, which help researcher to collect data. Research methods and/or techniques may be quantitative or qualitative in nature, resulting in designing research that is mixed in nature, i.e., it can be quantitative-qualitative, or vice versa. The researcher should answer the following questions: Did they choose research methods/techniques well? Are the research tools related to them of standardised nature (i.e., were constructed by other researcher and were standardised in specific research into an occurrence; they have to be used without a researcher's interference; sometimes, however, a researcher is adapting some standardised tool to their needs, but they need to explain in detail and substantively their interference in the tool's structure and contents) or were they developed by the researcher themselves? How many times have the tools been used to collect data and how long did it take? Are the tools still up-to-date and reliable? What is a sequence in which the researcher should use these tools (i.e., what are the stages of research)? (cf. Burns \& Grove, 2001).

The next step in a research procedure is selecting a sample subject to research. In connection with this, a researcher poses themselves the following questions: 
What population is the objective of research? How should a survey sample be selected: at random or purposefully/intentionally? What units should be a part of the sample: adults, teenagers or children, women, men, etc.? How big should a sample be, and what is the size of a sample selected for research? Can a selected sample be acknowledged to be representative (i.e., such in which the distribution of a selected variable is similar to its distribution in the population) for the general population (the size of the population itself is important)? A researcher should describe in detail the process of random or intentional selection of a sample because selecting a sample is a critical stage in designing research. To empirical research, specific people functioning under specific conditions are subject, and a change of the specificity of these people and research conditions may distort an image of explored dependencies or make it less clear. For this reason, repeating research into an analysed dependency many times, using various samples and research methods enables to eliminate errors, distortions, and, for example, to eliminate a random error or an error coming from the size of a sample.

The next stage is collecting data with the use of various research tools, tabulating them and presenting them graphically and statistically, falsifying hypotheses, a qualitative discussion and drawing conclusions. A researcher asks themselves, for example, the following questions: What should be a sequence in which to collect data? What tools will be used? Should the next tools have been modified after analysing the data acquired earlier? What tools were used? Were they constructed properly and were reliable data acquired with the use of them? What statistical techniques were used in data analysis? Were the value of a statistical test and the size of an assumed error given? Were statistical conclusions drawn properly? What was the level of confidence at which analyses were carried out? Does a narrative, e.g., concerning political science, sociological or pedagogical, capture the research results properly? Is it coherent, does it include objective argumentation and does it refer to all the data acquired? (cf. Holder, 2003). In a number of publications, the statistical significance of a link between variables is considered a measure of successful replication of scientific research. However, e.g., Rosenthal (1991) proves that this is not the statistical significance that is an indicator of successful replication, but some effect indicator, such as Cohen's $d$ statistics (a difference between the means divided by common standard deviation of both groups) or Pearson's $r$ correlation coefficient.

At last, here comes a time of formulating answers to research questions. Criticism of this stage of research aims at answering the following questions: Were all 
the research questions answered? Were the answers complete and exhaustive? It has a close link with the correct structure of research tools, selection of a sample and a researcher's correct procedure in the field. Were limitations concerning interpreting the conclusions drawn from the research determined? Was generalising the conclusions from a representative sample for the general population successful? Do the conclusions drawn fall into the theories that were used to design research? Were unexpected results achieved and how can the results be interpreted? (cf. Daggett, Harbaugh, \& Collum, 2005, pp. 255-258)

The last stage of scientific methodological criticism are recommendations concerning putting selected conclusions from the research into practice, determining the need to continue the research, indicating its further areas, or alternatively finding a new field of research, survey samples, research methods and techniques, seeking further correlations, dependencies, concerning specifying the course of an occurrence or process. In connection with the above, a researcher frames the following questions: Are the conclusions from the research that the researcher is proposing to put into practice relevant for recipients? What positive changes in the course of an occurrence can one expect owing to them? What contribution to a scientific discipline or sub-discipline did the research make? What is the next research that should be designed and carried out? (cf. Boswell \& Cannon, 2011, p. 296)

Methodological scientific criticism is aimed at eliminating errors in the procedure of designing research, makes it easier to construct reliable research tools, carry out research properly, carry out right quantitative and qualitative analysis of the research results, and then to draw conclusions and formulate recommendations for putting them into practice. Criticism reveals both strengths and weaknesses of a research project, indicates specific activities for improving the quality of research, broadens the knowledge about an occurrence and demonstrates the need to explore the next aspects of an occurrence or process (Rodger, 1997).

\section{METHODOLOGICAL SCIENTIFIC CRITICISM OF QUALITATIVE OR MIXED RESEARCH}

The term 'qualitative research' resembles an umbrella that is used to describe diverse qualitative research projects. "Qualitative researchers are interested in understanding how people interpret their experiences, how they construct their 
worlds, and how their understanding contributes to going through the next experiences" (Merriam, 2009, p. 5). In qualitative research, a researcher pays attention to the context of an occurrence and social and cultural aspects of an environment being studied. Research questions are more open and wider, less precise and hypothetical. A wider spectrum of subjects, of different ethnic origin, race, language, social class, age, and also of a different social rank, is used as compared to a sample selected in quantitative research, which is more homogeneous.

Qualitative research projects in social sciences refer to anthropological traditions and sociology, and their philosophy emphasises the phenomenological basis for research, it is sought to describe 'the significance' of an occurrence for people or a culture being analysed. This, in turn, refers to the 'verstehen' concept in the history of development of science. In a qualitative project, often one object, one case or an assemblage over a relatively long period is analysed. Referring to B. Glaser and A.I. Strauss' analyses (1967), qualitative data are often encoded a posteriori from an interpretation of these data. Qualitative research methods may be generalised under the name of ethnographic research, and within it we can differentiate case studies, field studies, grounded theory, analyses of official and personal documents, naturalistic inquiry, interviews and descriptive studies. Qualitative researchers analyse things in their natural environment, trying to construct their sense or interpret occurrences according to how people understand them (Merriam, 2009, p. 13).

Currently, all behavioural research is a construct containing a mixture of quantitative and qualitative research (cf. Creswell, 2003). Only quantitative or only qualitative research which, after all, we use in order to explore the objective reality, which reality is of complex nature, cannot be designed artificially. A dichotomous approach, artificially separating these two types of research (cf. Firestone, 1987), one applying 'logical' positivists' deductive research methods, and the other applying naturalists' (qualitative researchers) inductive methods, after the development of theories introduced, e.g., by Thomas Kuhn (1970), was converted into an interactive continuum approach, on the assumption that a dichotomous approach is not consistent with a coherent philosophy of science (is not its ontological construct) and on one more assumption that the notion of continuum is merely a construct that adjusts what we know in a scientific sense (Newman \& Ridenour, 1998; Maxwell, 1996). In a mixed approach, we differentiate various combinations of research, e.g.: qualitative $\rightarrow$ quantitative $\rightarrow$ qualitative, etc. Between the two paradigms, there is certain interactive continuum of research methods. In quantitative research, we emphasise its significance and generalis- 
ing it (Bryman, 2004), whereas in qualitative research we subject its credibility, dependence, reliability and verifiability to critical analysis in order to get a high level of accuracy of its results (Aveyard, 2010). Depending on whether research is quantitative-qualitative or vice versa, different approaches are adopted. The Critical Appraisal Skills Programme (CASP) (2010) led to developing the structure of assessing criticism tools that were validated in order to become certain that research can be appraised and assessed critically in a standardised manner.

Criticism of qualitative research is seeking answers to a bit slightly different questions than it was the case with quantitative research. This results from the absence of a stiff research structure, and a considerable degree of flexibility and the absence of certain elements in it, such as indication and operationalisation of variables or the formulation of hypotheses and their falsification. In particular situations, it can be even said of the absence of a research structure, which determines a researcher's peculiar action. They concentrate on an occurrence arousing their interest and try to identify all its aspects. Questions they ask themselves may be the following: Were the object and the objective of studies taken into account in research problems? Were the ethical requirements of research met? Was an environment in which research would be carried out recognised in full? What rational factors were predicted during the process of intentional selection of a sample? Are the data collection methods (e.g., interviews, document analysis, observations and open-ended questions in questionnaires) appropriate for the objectives of research and qualitative inquiry? Are individual steps in a systematic data analysis described clearly? Are research categories and subjects presented in a way that is clear to the reader? Does the researcher integrate their thinking processes with the area of research and the requirements of a magazine in which the research results are to be published? Were limitations of the carried out research, affecting the data collected and the description of an occurrence, identified?

It is happening more and more often that a research problem concerns a new area of research, in connection with this both the source literature and the existing theories may not be useful in constructing a research project. Then, a researcher is asking themselves more and more questions that are supposed to help them adopt a critical approach to the research project.

To a 'mixed' research project, questions may be framed that may apply to both quantitative and qualitative research, and then to a 'mixed' project in the following form: Is it rational to use 'mixed' methods in one research project? Does the discussion predict to integrate the two types of acquired data and 
demonstrate how they increase the cognitive value of the results achieved? Are chosen research methods and techniques complementary to each other? Will an image of an explored reality be coherent, complete and explained more fully? (cf. Palka, 2018).

Qualitative researchers use in their research different survey samples diversified not only in terms of age, sex or the level of education and the economic status, but the subjects' social rank is significant as well. Methods used in qualitative research have the potential for demonstrating dynamic aspects of an occurrence being studied: how information is transferred, for example, in the process of interaction and how it is used as measures or tools of social control of selected variables.

\section{CONCLUSIONS}

The process of methodological scientific criticism leads to an intense verification of each stage of a research process. This is not of criticism nature, but rather of an impersonal and objective analysis of each part of a project, using a balanced and objective approach the purpose of which is to indicate the project's strengths and weaknesses in order to identify when an analysed stage of research becomes trustworthy and objective. In the situation when a researcher is thinking about the types of concepts of research and their theoretical basis in quantitative research or structures of grounded theory as a result of carrying out qualitative research, they are constructing alternative research structures, related to research questions being framed and seeking relations between them. Considering adopting different research methods, they modify research questions, paying attention to the field of research and the sample being studied. Criticism of a research process is necessary both during the process of designing research, and during the process of collecting data, verifying and interpreting them because different epistemological and methodological traps are awaiting a researcher (cf. Dudzikowa \& Juszczyk, 2017). Without a critical approach, the likelihood of making an error in designing research or interpreting its results is increasing significantly and may even cause drawing wrong conclusions and result in willingness to put them into practice without reflection. Shaping a researcher's ability of assuming a critical approach, especially among junior research workers, in designing and analysing research results is a responsibility of experienced researchers, masters. 


\section{ReFERENCES:}

Ajdukiewicz, K. (1983). Zagadnienia i kierunki filozofii. Teoria poznania. Metafizyka. Warszawa: Czytelnik.

Aveyard, H. (2010). Doing a Literature Review in Health and Social Care: A Practical Guide ( $2^{\text {nd }}$ ed.). Bershire, England: Open University Press.

Babbie, E.R. (2013). The Practice of Social Research (13 ${ }^{\text {th }}$ ed.). Belmont, CA: Wadsworth Cengage Learning.

Boswell, C., \& Cannon, S. (2011). Introduction to Nursing Research: Incorporating Evidence Based Practice ( $2^{\text {nd }}$ ed.). Critique Process, chapter 13. Sudbury, Massachusetts: Jones \& Bartlett Learning.

Bryman, A. (2004). Social Research Methods. Oxford: Oxford University Press.

Burns, N., \& Grove, S.K. (2001). The Practice of Nursing Research: Conduct, Critique, and Utilization ( $4^{\text {th }}$ ed.). Boston: Jones \& Bartlett Publishers.

Carter, K. (2006). How to Critique Research. Retrieved from: http://www.runet. edu/ kcarter/Course_Info/nurs442/chapter12.htm.

Creswell, J.W. (2003). Research Design: Qualitative, Quantitative, and Mixed Methods Approaches ( $2^{\text {nd }}$ ed.). Thousand Oaks, CA: Sage Publications.

Critical Appraisal Skills Programme (CASP) (2010). Retrieved from: www.casp-uk.net/. CyberNurse (2005). Reading and Critiquing Research. Retrieved from: http://www. cybernurse.org.uk/research/reading_and_Critiquing_Research.htm.

Daggett, L., Harbaugh, B.L., \& Collum, L. (2005). A Worksheet for Critiquing Quantitative Nursing Research. Nurse Educator, 30(6), 255-258.

Denzin, N.K., \& Lincoln, Y.S. (eds.) (2000). The SAGE Handbook of Qualitative Research. Thousand Oaks: Sage.

Doroszewski, W. (ed.) (2017). Słownik języka polskiego [hasło: krytyka]. Warszawa: WN PWN. Retrieved from: http://sjp.pwn.pl/szukaj/krytyka\%20.html.

Dudzikowa, M., \& Juszczyk, S. (2017). Pułapki epistemologiczne i metodologiczne $w$ badaniach nad edukacją. Jak sobie z nimi radzić? Katowice: Wydawnictwo Uniwersytetu Śląskiego.

American Heritage Dictionaries (2005).

Firestone, W.A. (1987). Meaning in Method: The Rhetoric of Quantitative and Qualitative Research. Educational Researcher, 16(7), 16-21. DOI: 10.3102/0013189X016007016. Frankfort-Nachmias, Ch., \& Nachmias, D. (2001). Research Methods in the Social Sciences. London: Arnold.

Glaser, B., \& Strauss, A.I. (1967). The Discovery of Grounded Theory: Strategies for Qualitative Research. New York: Adeline.

Holder, B. (2003). The Research Critique. Retrieved from: http://virtual.clemenson.edu/ group/odce/summer1_03/nursT807/pdf.

Juszczyk, S. (2011). The Scientific Development of the Researcher in the Process of Shaping His Scientific Identity. The New Educational Review, 26(4), 17-29.

Kuhn, T. (1970). The Structure of Scientific Revolutions. Chicago: University of Chicago Press. 
Maxwell, J.A. (1996). Qualitative Research Design: An Interactive Approach. Thousand Oaks, CA: Sage.

Merriam, S.B. (2009). Qualitative Research: A Guide to Design and Implementation. San Francisco: Josey-Bass: A Wiley Imprint.

Newman, I., \& Ridenour, C. (1998). Qualitative-Quantitative Research Methodology: Exploring Interactive Continuum. Southern Illinois University Press. Retrieved from: http://ecommons/udayton.edu./eda_fac_pub/122.

Palka, S. (2018). Wiązanie podejść metodologicznych $w$ pedagogice teoretyczno-praktycznej. Kraków: IMPULS.

Polit, D.F., \& Beck, Ch.T. (2006). Essentials of Nursing Research: Methods, Appraisal, and Utilization ( $6^{\text {th }}$ ed.). Philadelphia: Lippincott Williams \& Wilkins.

Rosenthal, R. (1991). Replication in Behavioral Research. In: J.W. Neuliep (ed.), Replication Research in the Social Sciences (pp. 1-39). Newbury Park, CA: Sage Publications.

Rodger, B.L. (1997). Guidelines for Critique of Research Reports. Retrieved from: http:// www.uwm.edu/ brodg/Handout/critique.htm.

Tashakkori, A., \& Teddlie, Ch. (eds.) (2003). SAGE Handbook of Mixed Methods in Social and Behavioral Research. Thousand Oaks: Sage.

Valente, S. (2003). Critical Analysis of Research Papers. Journal for Nurses in Staff Development, 19(3), 130-142.

Vance, D.E., Talley, M., Azuero, A., Pearce, P.F., \& Christian, B.J. (2013). Conducting an Article Critique for a Quantitative Research Study: Perspectives for Doctoral Students and Other Novice Readers. Nursing Research and Reviews, 3, 67-75.

Voelker, D.H., \& Orton, P.Z. (1993). Cliff's Quick Review of Statistics. Lincoln: Cliff Notes. www.educationalrev.us.edu.pl. The Website of The New Educational Review. 